\title{
KUALITAS AIR PADA LOKASI BUDIDAYA IKAN DI PERAIRAN DESA ERIS, DANAU TONDANO, KABUPATEN MINAHASA
}

\author{
(Water Quality Parameters around the aquaculture area in the Eris waters, \\ Tondano Lake, Minahasa)
}

\author{
Sipriana S. Tumembouw ${ }^{1}$ \\ ${ }^{1}$ Fakultas Perikanan dan Ilmu Kelautan Universitas Sam Ratulangi, Manado.
}

\begin{abstract}
This study was aimed to measure water quality parameters around the cage farm in Erís. Fon dano Lake, and to assess whether the waters was still suitable for aquaculture activities or not Water was sampled from four stations based on the farm location and distances to the settlement Station I and station II represented the farm waters, while station III and station IV represented the waters close to community settlement. Measurements were conducted at two different depths, 0.5 meter below the surface and 0.5 meter above the bottom. Th water quality parameters measurent were tepperature, $\mathrm{pH}$, dissolved oxygen, turbidity, phosphate and ammonia. During the observation period the water quality parameters were measured four times in a seven-day interval. These were carried out in the morning, noon and afternoon, respectively. Results showed that water temperature, $\mathrm{pH}$, dissolfed oxygen and phosphate were still in the acceptable ranges for aquaculture, but turbidity and ammonia content have exceeded the threshold of water quality standard.

Keywords: Tondano Lake, water quality parameter, aquaculture.

Penelitian ini bertujuan untuk mengukur parameter kuditas air di sekitar keramba di Eris, Danau Tondano, dan untuk menduga apakah perairan terebut másih layak untuk aktifitas budidaya atau tidak. Air diambil dari empat stasiun berdasarkan lokasi budidaya dan jarak ke pemukiman penduduk. Stasiun I and stasiun II mewakili perairan tempat budidaya, sedangkan stasiun III dan stasiun IV mewakili perairan dekat daerah pemukiman. Pengukuran dilakukan pada dua kedalaman berbeda, yakni 0,5 meter di bawah permukaan dan 0,5 meter di atas dasar perăiran. Parameter yang diukur adalah suhu air, $\mathrm{pH}$, oksigen terlarut, kekeruhan, fosfat dan amonia. Selama masa pengamatan, parameter kualitas air diukur empat kali dengan interval waktu 7 hari. Hal ibi dilakukan pada pagi hari, siang hari, dan sore hari. Hasil menunjukkan bahwa suhu air, $\mathrm{pH}$, oksigen terlarut dan fosfat berada dalam kisaran yang layak untuk budidaya, tetapi kekeruhan dan kondungan amonia telah melewati batas ambang standar kualitas air.
\end{abstract}

Kata kunci: Danau Tondano, parameter kualitas air, budidaya.

\section{PENDAHUUUAN}

Danau adalah wilayah yang digenangi air sepanjang taliun yang terbentuk secara alami karena gerakkan kulit bumi sehingga bentuk dan ukurannya bervariasi. Danau digunakan sebagai tempat rekreasi, sumber pembangkit listrik (PLTA), sumber utama pengairan bagi usaha pertahian dan juga sebagai tempat pembudidayaan ikan (Waladow, 1997). Aktivitas akuakultur di danau Tondano menyumbang porsi yang cukup dominan terhadap total produksi perikanan tawar Sulawesi Utara. Salindeho dan Keppel (2004) menyatakan bahwa, meskipun aktivitas akuakultur di Sulawesi Utara dilakukan pada perairan danau, sungai, sawah, kolam dan irigasi, namun yang paling dominan produksinya, serta metode operasional secara in- tensif adalah budidaya ikan nila dan ikan mas pada Kurungan Jaring Tancap (KJT) di Danau Tondano. Diperkirakan jumlah produksi total ikan budidaya pada tahun 2003 di Danau Tondano sebesar 16.576,8 ton/tahun, yang diproduksi oleh para petani ikan di 20 desa (5 Kecamatan) sekeliling Danau (Salindeho et al. 2005).

Danau Tondano merupakan danau terbesar di Sulawesi Utara yang sekarang ini banyak mendapat perhatian dan sorotan dari berbagai kalangan karena ekologinya mulai terganggu seperti terjadinya proses degradasi yang mengakibatkan proses pendangkalan, penurunan debit air, banjir, gejala eutrofikasi (eceng gondok tidak terkendali (blooming), terganggunya kualitas air danau dan kematian ikan budidaya (Rompas et al. 1995). 
Aktivitas akuakultur di danau Tondano sudah berlangsung sejak awal tahun delapan puluhan, dan perkembangannya sangat pesat baik dari segi jumlah pembudidaya maupun dari total produksi per tahun. Salah satu kecamatan yang paling pesat perkembangan aktivitas akuakulturnya adalah kecamatan Eris, sedangkan desa yang paling pesat perkembangan akuakulturnya adalah desa Eris.

Salindeho dan Keppel (2002) melaporkan bahwa usaha budidaya ikan KJT di kecamatan Eris meliputi 5 desa yakni Watumea, Tandengan, Toulimembet, Eris dan Telap, dengan jumlah pembudidaya 326 orang. Produksi per siklus pemeliharaan, kurang lebih 3 bulan berkisar 5000 ton untuk kecamatan Eris dan merupakan produksi tertinggi di antara semua kecamatan di sekitar Danau Tondano. Ada 3 desa yang dominan dengan produksi melebihi 1000 ton per siklus adalah Telap Eris dan Tandengan.

Seiring dengan perkembangan yang sangat pesat, muncul permasalahan-permasalahan yang cukup kompleks dimana yang paling dominan adalah kondisi kualitas air danau yang terdegradasi secara konsisten dan perkembangan eceng gondok yang sangat pesat. Kondisi ini berimplikasi pada turunnya intensitas akuakultur serta pada akhirnya total produksi perikanan akuakultur menurun tajam. Wehantouw (2005) melaporkan bahwa, periode 2003-2005 terjadi penurunan yang signifikan pada total prơduksi ikan dari desa Eris. Tahun 2003, totat produksi sebesar 4.800 ton dan jumlah ini berkurang menjadi 1.650 ton di tahun 2004 dan 723,6 ton di tahun 2005. Data terakhir yang dilaporkan Wagiu (2009), menunjukkan telah mulai terjadi peningkatan produksi dimana tahun 2009 produksi ikan mas di đasa'Eris berkisar 1.050 ton. Selanjutnya, pergembangan usaha sedang dilakukan dengan menambah jumlah KJT sebanyak 250 unit, dêngan harapan jumlah produksi ikan akan bertambah 900.000 ekor per tahun.

Perkembangan unit karamba jaring apung (KJA) dan KJT pada areal budidaya yang kurang terkendali akan menimbulkan dampak negatif terhadap lingkungan perairan. Masalah yang timbul adalah pencemaran lingkungan akibat dari berbagai kegiatan di sekitar perairan maupun dari usaha budidaya itu sendiri. Contoh masalah lingkungan dari usaha budidaya adalah pakan yang diberikan tidak dikonsumsi dengan baik oleh ikan. Sisa pakan akan mengendap di dasar perairan lalu terjadi proses dekomposisi oleh mikroorganisme (Sastrawijaya, 1991). Dalam proses ini dibutuhkan oksigen dalam jumlah yang besar. Bila suplai oksigen tidak cukup, kondisi anaerob pada dasar danau tidak dapat dihindari yang bisa menghasilkan substansisubstansi beracun seperti amoniak, nitrit dan sulfur yang secara tidak langsung sudah merubah sifat fisik dan kimia dari perairan.

Penelitian ini dilakukan di lapangan Desa Eris dan di laboratorium Fakultas Perikanan dan Ilmu Kelautan UNSRAT.

\section{METODE PENELITIA}

Pengambilan sampel afr dilakukan pada 4 stasiun yang telah ditentukan berdasarkan pertimbangan aktivitas budidaya ikan dan letak pemukiman. Stasiun dan-1I mewakili lokasi sekitar aktivitas budidaya ikan. Stasiun III dan IV mewakili lokasi sekitar pemukiman penduduk. Pengukuran sampel air (in situ) dilakukan sebanyak 4 kali (sampling I-IV) dengan interval waktû 1 minggu pada pagi (07.00-09.00), siang (12.00-14.00) dan sore (16.00-18.00). Untuk parameter suhu dan derajat keasaman (pH) pengambilan sampel dilakukan di 2 kedaJaman yaitu $0,5 \mathrm{~m}$ dari permukaan air dan $0,5 \mathrm{~m}$ dari dasar danau. Metode pengukuran dan parameter kualitas air disajikan dalam bentu tabel dan grafik, kemudian dibandingkan dengan baku mutu air dalam PP RI. No. 82 Tahun 2001 Tentang Pengelolaan Kualitas Air dan Pengendalian Pencemaran Air.

Tabel 1. Metode analisis parameter kualitas air

\begin{tabular}{clll}
\hline No & Parameter & Satuan & Alat \\
\hline 1 & Temperatur & ${ }^{\circ} \mathrm{C}$ & Termometer \\
2 & Kecerahan & $\mathrm{m}$ & Pinggan sechi \\
3 & Kekeruhan & $\mathrm{NTU}$ & Turbidimeter \\
4 & $\mathrm{pH}$ & - & $\mathrm{pH}$ \\
5 & DO & $\mathrm{mg} / 1$ & DO meter \\
6 & Amoniak $\left(\mathrm{NH}_{3}{ }^{+4}\right)$ & $\mathrm{mg} / 1$ & Spectrophotometer \\
7 & Fosfat $\left(\mathrm{PO}^{-}\right)$ & $\mathrm{mg} / 1$ & Spectrophotometer \\
\hline
\end{tabular}

\section{HASIL DAN PEMBAHASAN}

\section{Suhu}

Hasil pengukuran suhu di stasiun I-IV pada kedalaman $0,5 \mathrm{~m}$ bervariasi, suhu paling tinggi berada pada stasiun I sampling I yakni pada siang hari, dan suhu terendah berada pada stasiun I sampling II yakni pada pagi hari (Gambar 1). Hal ini disebabkan keadaan cuaca hujan sedangkan sampling III dan sampling IV keadaan cuaca cerah. Pengukuran pada cuaca cerah, suhunya meningkat karena permukaan 
perairan terkena cahaya matahari secara langsung. Hasil pengukuran menunjukkan bahwa suhu berada pada kondisi alami yaitu berkisar antara $24,7^{\circ} \mathrm{C}-28,3^{\circ} \mathrm{C}$.

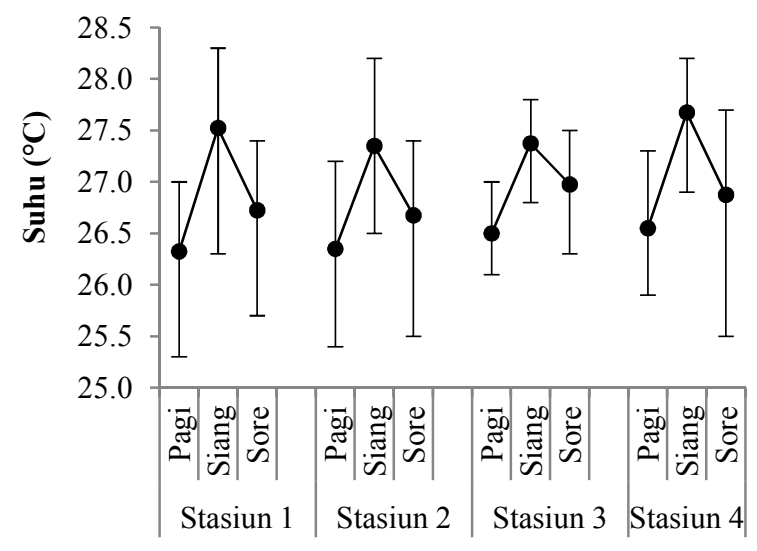

Gambar 1. Fluktuasi suhu harian perairan desa Eris, Danau Tondano.

\section{Kekeruhan}

Nilai kekeruhan terendah berada pada sampling I stasiun II (Gambar 2), hal ini disebabkan pada saat pengambilan sampel lokasi ini cukup bersih, tidak ada buangan limbah rumah tangga dan kurangnya tumbuhan eceng gondok, yang diduga limbah yang ada pada lokasi ini hanyut terbawa arus. Sedangkan kekeruhan tertinggi berada pada sampling IV stasiun I pengambilan sampel lokasi ini terdapat penyimpanap pakan yang pada saat pengukuran cuaca buruk (hujan dan angin kencang), yang menyebabkan wadah tempat penyimpanan pakan cusak sehingga pakan banyak terbuang ketperairan.

\section{Oksigen Terlarut (DO)}

Di stasiun I, DQ berkisar antara 7,10$7,52 \mathrm{mg} / \mathrm{l}$, stasiun IF 7, 18-7,52 mg/1, stasiun III $7,18-7,52 \mathrm{mg} / 1$ dapostasiun IV 7,33-7,44 mg/1 (Gambar 3). Stasiun dan II, hasil yang diperoleh sampling T dán II lebih tinggi dibandingkan dengan sampling III dan IV. Begitu juga hasil yang diperoleh dari pengukuran di stasiun III dan IV. Hal ini disebabkan keadaan cuaca mendung dan hujan. Saat mendung dan hujan, cahaya matahari yang masuk ke dalam perairan berkurang sehingga suhu rendah dan DO meningkat. Salindeho et al. (2005) melaporkan bahwa level DO pada perairan Danau Tondano berkisar antara $3,53-5,76 \mathrm{mg} / 1$.

\section{Derajat Keasaman (pH)}

Dari hasil pengukuran stasiun I di kedalaman $0,5 \mathrm{~m}$ dari permukaan air $\mathrm{pH}$ tertinggi di sampling I $(8,03)$ pada siang hari dan terendah sampling II $(6,92)$ pada pagi hari (Gambar 4). Sedangkan hasil di kedalaman $0,5 \mathrm{~m}$ dari dasar danau tertinggi sampling IV $(8,03)$ pada pagi hari dan terendah sampling II $(7,10)$ pada pagi hari. Peningkatan $\mathrm{pH}$ tertinggi diperkirakan buangan limbah sabun dan diterjen dari lingkungan sekitar yang masuk ke danau. Baku mutu kualitas air untuk aktivitas akuakultur merekomendasikan $\mathrm{pH}$ air berkisar 6-9. Salindeho, et al. (2005) melaporkan bahwa, nilai $\mathrm{pH}$ perairan danau Tondano berkisar antara 7,1-8,0.

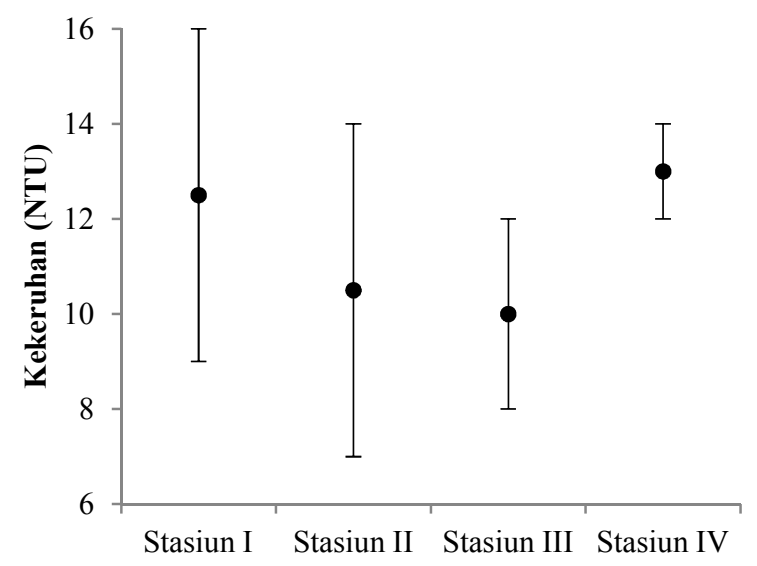

Gämbar 2.' Nilai kekeruhan perairan desa Eris, pada 4 stasiun berbeda.

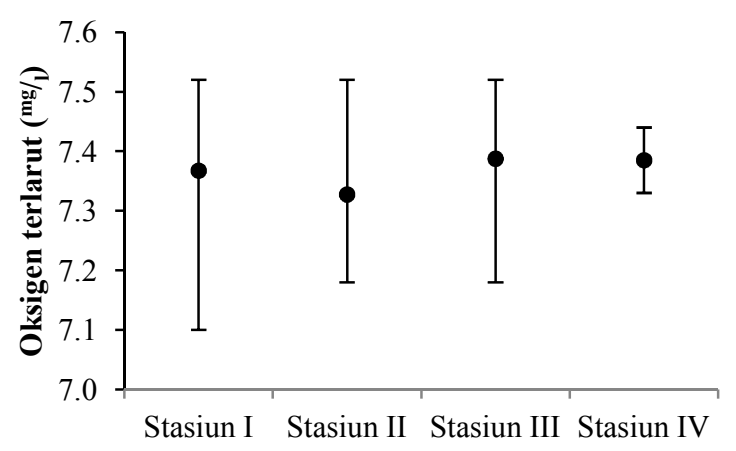

Gambar 3. Nilai oksigen terlarut perairan desa Eris, Danau Tondano pada 4 Stasiun yang berbeda.

\section{Amoniak ( $\left.\mathbf{N H}_{3}\right)$}

Hasil penelitian (Gambar 5) menunjukkan amoniak tertinggi di stasiun IV sampling IV yaitu $0,14 \mathrm{mg} / 1$ dan terendah stasiun I sampling I yaitu $0,03 \mathrm{mg} / 1$. Pada stasiun IV banyak terdapat buangan limbah domestik. Sampahsampah menumpuk dan hanya dibiarkan begitu saja. Sedangkan di stasiun I yang letaknya ke tengah bagian danau kurang terlihat adanya buangan limbah domestik. Namun pada sampling IV kadar amoniak meningkat di stasiun I. Amoniak dalam air berasal dari kotoran organisme, pembusukan atau penguraian bahan organik. Baku mutu kualitas air untuk aktivitas akuakul- 
tur merekomendasikan konsentrasi amoniak berkisar $<0,02 \mathrm{mg} / \mathrm{s}$.

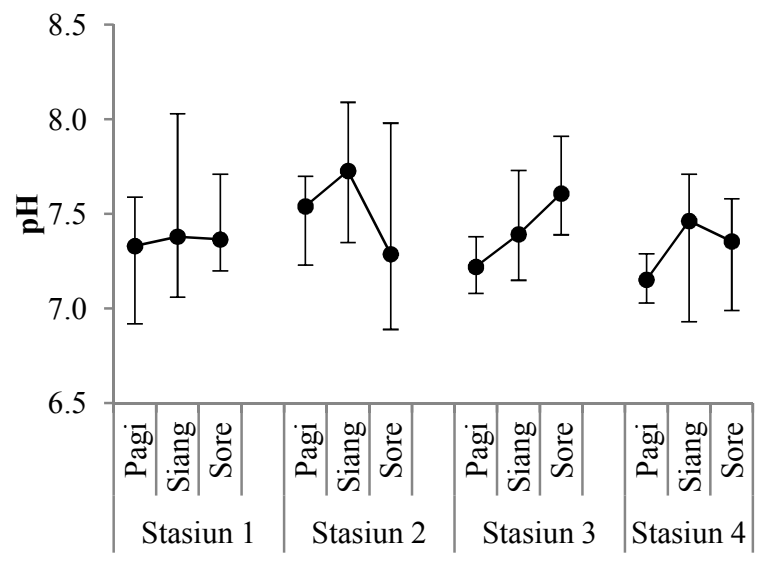

Gambar 4. Fluktuasi harian nilai $\mathrm{pH}$ perairan desa Eris, Danau Tondano pada 4 stasiun.

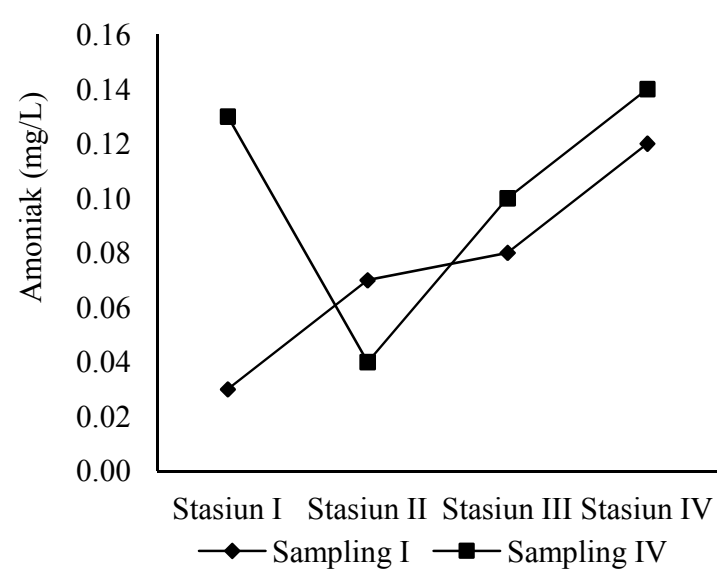

Gambar 5. Konsentrasi amoniak perairan deså Eris, Danau Tondano pada empat stasiun berbeda.

\section{Fosfat $\left(\mathrm{PO}_{4}\right)$}

Hasil penelitian menurjukkan kandungan fosfat di stasiun I yaitu $0,02 \mathrm{mg} / 1$ sampling I dan $0,07 \mathrm{mg} / 1$ sampling $\mathrm{IV}$, stasiun II yaitu 0,03 $\mathrm{mg} / 1$ sampling I dan $0.40 \mathrm{mg} / 1$ sampling IV, stasiun III yaitu $0,03 \mathrm{mg} / 1$ sampling I dan $0,09 \mathrm{mg} / 1$ sampling IV dan stasiun IV $0,05 \mathrm{mg} / \mathrm{l}$, sampling I dan $0,12 \mathrm{~m} / \mathrm{s}$ samling IV. Kandungan fosfat tertinggi berada pada sampling IV stasiun IV. Hal inj disebabkan oleh intensitas kegiatan mencuci dan buangan limbah rumah tangga yang tinggi ke perairan. Baku mutu kualitas air untuk aktivitas akuakultur merekomendasikan kandungan fosfat adalah $1 \mathrm{mg} /{ }_{1}$. Salindeho et al. (2005) mendapatkan kandungan fosfat yang sangat tinggi di perairan desa Eris, dengan nilai fosfat $1,29-4,43 \mathrm{mg} / \mathrm{s}$. Hasil penelitian sekarang ini mengindikasikan bahwa telah terjadi penurunan konsentrasi fosfat yang cukup signifikan di perairan Danau Tondano dalam jangka waktu 6 tahun.

\section{KESIMPULAN}

Parameter kualitas air di perairan Desa Eris Danau Tondano yakni suhu, derajat keasaman $(\mathrm{pH})$, oksigen terlarut (DO) dan fosfat $\left(\mathrm{PO}_{4}\right)$ masih berada pada taraf yang Jayak dan sesuai dengan taraf yang direkomendasikan oleh baku mutu kualitas air, sedangkan kekeruhan dan kandungan amoniak $\left(\mathrm{NH}_{3}\right)$ tidak layak.

Hasil penelitian ini diharapkan menjadi masukkan penting bagi peunbudidaya ikan maupun instansi pemerintah dan non-pemerintah terkait, untuk bersama-sama melakukan usaha perbaikan kualitas aip Danau Tondano, khususnya kekeruhan dan konsentrasi amoniak.

\section{GAFTAR PUSTAKA}

Rompas RM, Masengi KWA, Pangemanan NP, Moningkey R, Kawung N. 1995. Ekologi Danau Tondano. Laporan Penelitian Fakultas Perikanan UNSRAT. Proyek Penelitian Kawasan Kritis DAS Tondano Tahun Anggaran 1995/1996 Kabupaten Minahasa. Manado. 15 hal.

Salindeho IRN, Keppel RC, 2002. Kondisi Perikanan Budidaya di Kabupaten Minahasa. J. perikanan dan Kelautan. 1(4): 33-39.

Salindeho IRN, Keppel RC, 2004. Kajian Ekonomi Perikanan Budidaya di Sulawesi Utara. J. Perikanan dan Kelautan. 2(2): 20-26.

Salindeho IRN, Pangemanan NP, Arifin H, 2005. Kajian daya dukung perairan Danau Tondano dengan parameter fosfor (P) untuk aktivitas akuakultur. J. Perikanan dan Kelautan. 1(1): 26-35.

Sastrawijaya TA, 1991. Pencemaran Lingkungan. Penerbit PT. Rineke Cipta. Jakarta. 247 hal.

Wagiu MH. 2009. Risiko pemasaran, kasus pembudidaya ikan mas di desa Eris, Minahasa. J. Perikanan dan Kelautan. 5(2): 77-82.

Waladow LOW. 1997. Beberapa Parameter Fisika, Kimia dan Biologi Danau Linou. Skripsi. FPIK. Unsrat. Manado. 37 hal.

Wehantouw A. 2005. Fluktuasi produksi perikanan budidaya perairan Danau Tondano. Laporan Hasil Penelitian. Universitas Sariputra, Tomohon. 40 hal. 